Farhad Rahmanov,

Dr. Sc., Professor, Azerbaijan State University of Economics (UNEC), Republic of Azerbaijan

iD ORCID ID, 0000-0003-2911-8179

email: farhad52@live.ru

Ramilya Aliyeva,

Ph. D., The Academy of Public Administration under the President of the Republic of Azerbaijan, Republic of Azerbaijan

iD ORCID ID, 0000-0002-2009-2921

email: r.agazade@hotmail.com

Anna Rosokhata,

Ph.D., Sumy State University, Ukraine

ORCID ID: 0000-0001-6944-1515

email: a.rosokhata@gmail.com

Nataliia Letunovska,

Ph.D., Sumy State University, Ukraine

ORCID ID: 0000-0001-8207-9178

email: n.letunovska@gmail.com

Correspondence author: farhad52@live.ru

\title{
TOURISM MANAGEMENT IN AZERBAIJAN UNDER SUSTAINABLE DEVELOPMEN: IMPACT OF COVID-19
}

Abstract. The article is devoted to the current issue of 2020 on the impact of the COVID-19 pandemic on the tourism industry in general, Azerbaijan in particular, and overcoming this crisis, taking into account the main aspects and goals of sustainable development. The primary purpose of the article is to form recommendations for compliance with the goals of sustainable development in the tourism industry of Azerbaijan with the levelling of events caused by the influence of COVID-19. A review of the scientific literature concluded that the issue of tourism marketing in crisis conditions is always complicated and multifaceted. The development of the tourism sector is a positive change for the host countries, which helps to solve problems in other areas of the economy. The article presents the dynamics of development of the tourism industry in recent years in the world, in the group of Middle East countries, which respectively includes Azerbaijan. The leading quantitative indicators of tourism development in Azerbaijan, neighbouring countries, and Ukraine were compared. The relevance of this study is that a systematic restart of the tourism sector after the end of quarantine measures is a necessary condition to take into account all the preferences, requests, and concerns of citizens who are direct participants in the economic component of tourism. During the preparation of the material, a marketing survey of Azerbaijani citizens was conducted to study the potential impact of COVID-19 on the tourism industry. The survey was conducted on April 13-21, 2020, by a team of researchers from the University of Northampton (UK), the National Institute of Geophysics, Geodesy and Geography at Bulgarian Academy of Sciences, University of National and World Economy (Bulgaria). The article highlights the main results of this study, based on which the critical inquiries of Azerbaijani citizens regarding the restart of tourism in the country were formed. The analytical method of the article analyzes the goals of sustainable development, announced following the Resolution adopted by the UN General Assembly on September 25, and which become most relevant in the context of 2020 and are a challenge for modern society and Azerbaijan in particular. As a result of this study, recommendations were made to restart the tourism sector in Azerbaijan, given compliance with and implementation of sustainable development goals. The results of this study can be useful for the governing institutions of Azerbaijan and other countries in which the tourism industry has developed dynamically and rapidly over the past few years.

Keywords: tourism, sustainable development goals, COVID-19 impact, social aspects of tourism, tourist choice, restart of tourism, health of citizens.

Cite as: Rahmanov, F., Aliyeva, R., Rosokhata, A., \& Letunovska, N. (2020). Tourism Management in Azerbaijan Under Sustainable Development: Impact of COVID-19. Marketing and Management of Innovations, 3, 195-207. http://doi.org/10.21272/mmi.2020.3-14 
F., Rahmanov, R., Aliyeva, A., Rosokhata, N., Letunovska. Tourism Management in Azerbaijan Under Sustainable Development: Impact of COVID-19

Introduction. The COVID-19 pandemic is one of the most significant and most unpredictable events of recent years. Virtually everyone will support the idea that the world has not seen such a large-scale crisis and panic for a long time, and perhaps never before. Every country, economy, and sphere of human activity has not escaped the events that are unfolding since the beginning of 2020 . Thus, for reducing the spread of the COVID-19 virus, one of the main requirements for citizens of almost all countries was the restriction of long-distance travel, the ability to leave their home, city, district, region, and country. Of course, such restrictions have primarily suspended tourism both globally and nationally. The virus is the same everywhere, and in most cases, the government takes the right measures to suspend communication between citizens. However, there are still countries that are more affected by the disease and therefore remain closed to international tourism. Thus, these events pushed us back 20-30 years ago in the pace of tourist movement at the global level, and this is especially noticeable in countries where the pace of tourism development has grown significantly in recent years. Recently, Azerbaijan has been the country that has shown the intensification of the tourism sector. According to the official data of the Institute of Economics of the National Academy of Sciences of Azerbaijan, in 2018, the tourism sector was named one of the critical sectors of the economy (Allahverdiyeva, 2017). It combines not only a large number of tourism enterprises but also the ones indirectly related to tourism industries involved in the process of providing tourist services. Given this, the situation of sharp restrictions on tourism for Azerbaijan as well as for other countries has a significant negative impact on different sectors of the economy and the economy as a whole (Bilan et al., 2019). For meeting the sustainable development goals announced by the UN General Assembly and to comply with necessary epidemiological measures to reduce the spread of COVID-19, tourism should be changed and refocused.

Considering the situation from the standpoint of adherence to the goals of sustainable development, announced following the Resolution adopted by the UN General Assembly on September 252015 (Assembly, 2015). On the one hand, one of the goals is to ensure a healthy lifestyle and well-being of people of all ages. It is, of course, paramount and vital, relevant to all humanity. Still, on the other hand, the list of goals also includes the promotion of continuous, inclusive and sustainable economic growth, full and productive employment and decent work for all. Thus, there is an urgent need to find and implement new forms and means of ensuring the development of tourism, especially for countries where the industry was key to the economy before the events of 2020 and which involved a significant amount of resources, including human. The article purpose is to form recommendations for compliance with the goals of sustainable development in the tourism industry of Azerbaijan with the levelling of events caused by the influence of COVID-19. There are several tasks in the paper. Firstly, it is the investigation of the tourism industry state in Azerbaijan in 2020 significantly changed by quarantine measures because of COVID-19. Then, it is the search of alternatives to stabilize and restart tourism in Azerbaijan while achieving the sustainable development goals under financial stabilization and equal distribution of benefits and simultaneous compliance with all security measures to preserve the health of citizens. Besides, the issue of further development and economic security is relevant not only to review the current crisis caused by the pandemic but also due to other economic and social processes of today, which are devoted to a large number of scientific papers( Melnyk et al., 2018; Yevdokimov et al., 2018; Bilan et al., 2019; Ibragimov et al., 2019, Rosokhata et al., 2020). The provision of recommendations for a systematic way out of the crisis in compliance with the goals of sustainable development of humanity is a significant issue. The authors of this paper put forward the following hypotheses of the study:

$\mathrm{H} 1$ : When planning a future trip, potential tourists take into account several factors: financial capacity, opportunities of tour operators, the risks of staying in other countries. When choosing a country of travel, they are taken into account together.

$\mathrm{H} 2$ : Tourists who plan to resume their travels within their country plan to travel on their transport and organize their trips. 
F., Rahmanov, R., Aliyeva, A., Rosokhata, N., Letunovska. Tourism Management in Azerbaijan Under Sustainable Development: Impact of COVID-19

H3: Tourists planning to visit foreign countries will be more likely to choose tours organized by tour operators as opposed to self-organized tourism.

Literature Review. Due to the events of recent years, in the research of scientists on tourism, more and more attention is paid to the health aspects. The possible positive impact of tourism on compliance with the conditions of global sustainable development and the implementation of preventive measures to curb the spread of the dangerous virus COVID-19 is analyzed. The authors of this research analyzed the most relevant works of scientists that have appeared recently and relate to the development of tourism in the complex conditions of the pandemic. Many scientists call tourism for health improvement one of those types of tourism that are developing at the fastest pace compared to others. Health is said to be one of the determinants of tourist behaviour and motivation (Lee et al., 2020). The authors of this work explore the elements of travel that have a positive impact on the domestic tourism industry.

The author of the work (Alexis-Thomas, 2020) actively explores issues related to tourism opportunities to make a significant contribution to building the strong potential of the nation in compliance with the goals of sustainable development until 2030. The researcher in the study (Wang, 2017) examines the economic and cultural impact of tourism on the territory, in particular, considers its marketing aspects. The paper (Vucetic, 2018) argues that the issue of sustainable development through the prism of the tourism industry is especially urgent for countries in transition. At the same time, through tourism, such countries are trying to achieve better development indicators in both economic and non-economic spheres. The authors (Lee et al., 2019) explore the possibilities of tourism to achieve sustainable development goals through surveys of respondents on the specified characteristics. They consider three types of tourism impact: economic, socio-cultural, and sustainable development in the environment at three tourism development stages (involvement, development, consolidation). This idea of distinguishing the three components of the impact of tourism is supported by many scholars, defining the word «sustainable» by a combination of social, environmental, and economic definitions (Mazilu et al., 2017). The authors of the paper (Martin et al., 2017) call tourism a tool that has proven to be one that serves to achieve sustainable rural development and has both positive and negative effects. They conducted a comprehensive assessment of the impact of rural tourism on the environment of suburban areas. In (Kabote et al., 2017), using content analysis of the scientific literature, the authors try to prove that tourism is a panacea for sustainable development, the use of all the benefits of which leads to a real increase in quality of life in the host country. Several scientists investigate the concept of responsible tourism. Scientists consider responsibility as an obvious parameter of the tourism industry. It is a fundamental factor that determines the behaviour of tourists and their perception of the tourist product (Saarinen, 2018).

In Aimagambetov (2017) there are several models of development of the tourism industry, which are primarily determined by the level of development of the country: organic model of development, traditional model of non-intervention, enclave tourism development model, from the centre to the periphery model. The last one is typical for Kazakhstan and most of the former CIS countries. Interesting is the study (Hatipoglu, 2019), in which the authors consider the features of the use of the concept of socially responsible business in the field of tourism and determine the benefits of its achievements for society. The paper argues that all tourism entities are potentially able to think strategically about compliance with the conditions of social responsibility and bring a significant positive impact on the socio-economic situation of the regions of their location and operation. The study Adongo (2018) analyzed different groups of tourists with their different attitudes to the principles of sustainable development (tourists with anthropocentric traits and tourists with ecocentric traits). The author's approach to the study of tourism development makes it possible to build a model of the relationship between the studied values of tourists, economic development, and sustainable development in the field of tourism. The issues of sustainable development in the field of tourism are also addressed in the works of Ukrainian scientists who carry out practically targeted research on the example of active regions in Ukraine, which attract a large number of 
F., Rahmanov, R., Aliyeva, A., Rosokhata, N., Letunovska. Tourism Management in Azerbaijan Under Sustainable Development: Impact of COVID-19

tourists (Shcherbakova, 2018). Researchers Van Dyk et al. (2019) analyze the motivation of tourists, dividing them into two different groups - first-time tourists and repeat tourists, emphasizing that the behaviour of these two groups differs significantly in some parameters.

Methodology and research methods. Analytical and empirical research are the methodological basis of the article. The main results of the work were formed based on the marketing research of the citizens of Azerbaijan to study the potential impact of COVID-19 on the tourism industry. The survey was conducted on April 13-21, 2020 by a team of researchers from the University of Northampton (UK), National Institute of Geophysics, Geodesy and Geography at the Bulgarian Academy of Sciences, University of National and World Economy (Bulgaria). The sample included 417 citizens, where $69 \%$ were women, and $31 \%$ were men. About $50 \%$ of respondents are young people under 24 years old. The hypothesis of the scientific work was the assumption that as a result of the declared pandemic from COVID-19, most people, who were previously an active tourist community, will change their priorities in tourist preferences.

Results. According to the Report of International Tourism Highlights (2019 Edition) at the global level, the tourism industry grew every year until 2018 (Fig. 1).

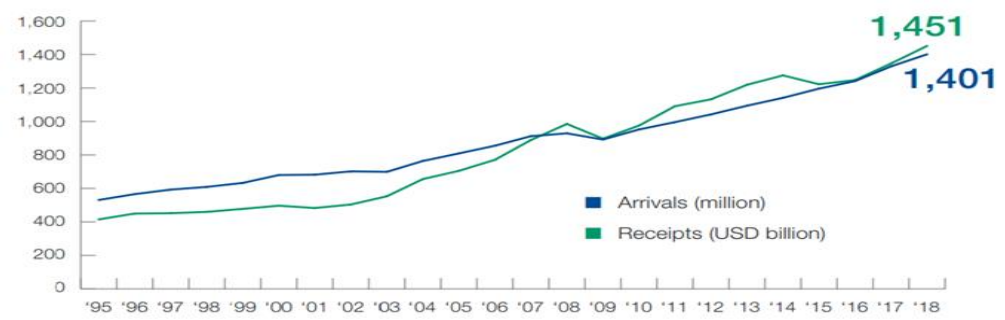

Figure 1. International tourist arrivals (million) and tourism receipts, USD billion Source: World Tourism Organization (UNWTO), July 2019.

In 2019, the World Tourism Organization registered 1.5 billion international tourist trips around the world, which indicates a 4\% increase compared to 2018. The same growth forecast was for 2020 (World Tourism Organization (UNWTO) World Tourism Barometer, 2020). But the events caused by the COVID19 pandemic dramatically changed the current situation in world tourism (Fig. 2) in all geographical regions of the world, including middle east countries (Fig. 3).

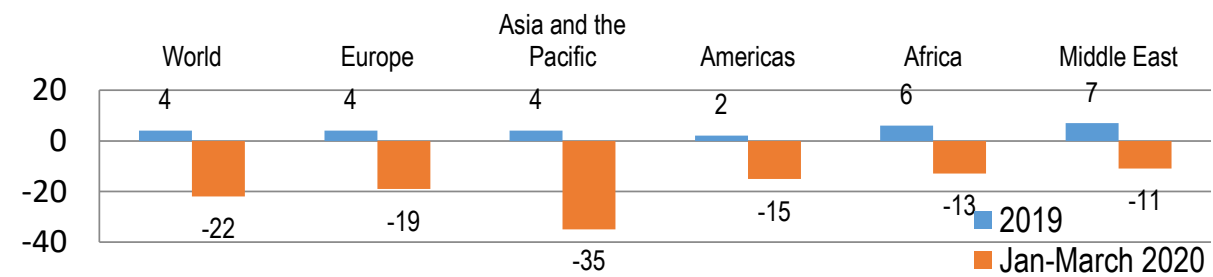

Figure 2. International tourist arrivals, 2019 and January-March 2020 (\% change) Source: World Tourism Organization (UNWTO), May 2020. 
F., Rahmanov, R., Aliyeva, A., Rosokhata, N., Letunovska. Tourism Management in Azerbaijan Under Sustainable Development: Impact of COVID-19

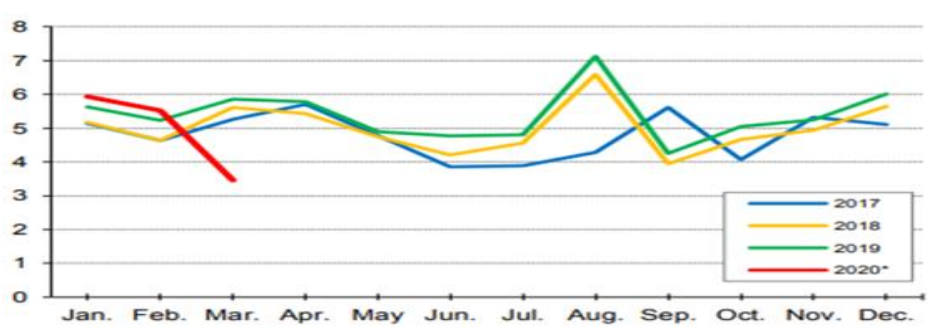

Figure 3. International Tourist Arrivals by month. Middle East (million)

Source: World Tourism Organization (UNWTO), May 2020

As for the situation in Azerbaijan, it is quite critical even in comparison with other countries in the region (Table 1). The number of patients with COVID-19 in Azerbaijan at the time of writing this paper is increasing. As of July 202020 , the military conflict on the border with Armenia has intensified, which is also a negative factor in attracting tourist flow to the country. As a result, the central forecast that can be made for the development and restart of the tourist flow in Azerbaijan in 2020 is disappointing, and from the standpoint of attracting international tourism is currently primarily dangerous. However, at the same time, it should be emphasized that the citizens of Azerbaijan, despite the critical data, in principle, at the time of the weakening of quarantine measures in the future may begin to move within the country, which will be the basis for the transformation of domestic tourism. An example is Ukraine. Quarantine measures have significantly reduced the flow of international tourism due to the necessary two-week observation of those arriving in the country. However, some of the Ukrainian citizens began to use the opportunity of moving within the country in certain regions.

Table 1. International Tourist Arrivals by (sub)region and selected countries and territories of destination

\begin{tabular}{|c|c|c|c|c|c|c|c|c|c|c|c|c|c|c|}
\hline & & & & & & & & erce & $\begin{array}{l}\mathrm{ge} \mathrm{cl} \\
\text { of } \mathrm{t}\end{array}$ & $\begin{array}{l}\text { lange } c \\
\text { he pre }\end{array}$ & $\begin{array}{l}\text { over } \\
\text { vious }\end{array}$ & $\begin{array}{l}\text { ne san } \\
\text { year }\end{array}$ & e per & \\
\hline & & 100 & point & & Cha & ige (\%) & & & 020 & & & & 19 & \\
\hline Period & 2010 & 2015 & 2018 & 2019 & $18 / 17$ & $19 / 18$ & Q1* & Jan. & Feb. & Mar. & Q1* & Q2* & Q3* & Q4* \\
\hline Azerbaijan & 1,28 & 1,922 & 2,605 & & 6,2 & & $-14,9$ & 18,1 & 15,8 & $-62,2$ & $-2,8$ & 14,9 & 14,2 & 17,4 \\
\hline Armenia & 687 & 1,192 & 1652 & 1,894 & 10,5 & 14,7 & & & & & 5,2 & 19,5 & 16,9 & 15,6 \\
\hline Georgia & \begin{tabular}{|l|l}
1,067 \\
\end{tabular} & 3,012 & 4,757 & 5,08 & 16,9 & 6,8 & $-13,2$ & 18,9 & 4 & $-56,1$ & 5,1 & 13,8 & 1,4 & 10,7 \\
\hline Ukraine & 21,203 & 12,886 & 14,207 & & $-1,5$ & & & & & & $-7,5$ & $-4,3$ & -5 & \\
\hline
\end{tabular}

${ }^{*}$ Q1: January, February, March; Q2: April, May, June; Q3: July, August, September; Q4: October November, December

Source: World Tourism Organization (UNWTO) World Tourism Barometer. Statistical Annex (2020).

From the standpoint of tourism marketing, it is impossible not to take into account the demands and general mood of citizens. Thus, on the one hand, they are the objects of influence of travel agencies and tourism business in general. At the same time, the citizens are entities engaged in tourism and are direct participants in the process. A team of researchers from the University of Northampton (UK), the National Institute of Geophysics, Geodesy and Geography at the Bulgarian Academy of Sciences, the University of National and World Economy (Bulgaria) conducted a marketing survey on the attitude of Azerbaijani citizens to the potential impact of COVID-19 on the tourism industry. The sample included 417 citizens, where $69 \%$ were women, and $31 \%$ were men. More than $50 \%$ of respondents are young people under the age of 24, which until the events of 2020 was the leading stratum of those interested and the most motivated category of the population in terms of tourism because young people are the most progressive 
F., Rahmanov, R., Aliyeva, A., Rosokhata, N., Letunovska. Tourism Management in Azerbaijan Under Sustainable Development: Impact of COVID-19

and decisive part of society. Among the respondents, $42 \%$ are still studying, $44 \%$ were employees working in Azerbaijan, $1.7 \%$ - retirees, $7.2 \%$ - housewives and unemployed, and $5.3 \%$ - people with other activities. About $88 \%$ of respondents have higher education. About $39 \%$ of them have a family or live in a civil marriage. It confirms the representativeness of the sample. Respondents socially realized, in addition to that, they have free time, access, and opportunities to travel, and therefore they are potential tourists. Table 2 shows the detailed characteristics of the sample of the study. According to the results of the research, more than half of respondents with a high degree of caution will resume their tourist trips (Fig. 4).

Table 2. The respondents' demographic and socio-economic details

\begin{tabular}{|c|c|c|}
\hline Variables & Categories & Percentage in the sample \\
\hline \multirow{2}{*}{ 1. Gender } & Female & $68.6 \%$ \\
\hline & Male & $31.4 \%$ \\
\hline \multirow{5}{*}{ 2. Age (years) } & $18-24$ & $49.6 \%$ \\
\hline & $25-34$ & $16.5 \%$ \\
\hline & $35-44$ & $13.2 \%$ \\
\hline & $45-54$ & $12.7 \%$ \\
\hline & $55+$ & $7.9 \%$ \\
\hline \multirow{8}{*}{ 3. Occupation } & Pupil/student & $42.2 \%$ \\
\hline & Civil servant/employee of a state enterprise & $24.7 \%$ \\
\hline & Own business & $3.6 \%$ \\
\hline & Freelancer & $1.4 \%$ \\
\hline & An employee in a private company & $13.9 \%$ \\
\hline & Pensioner & $1.7 \%$ \\
\hline & Housewife/unemployed & $7.2 \%$ \\
\hline & Other & $5.3 \%$ \\
\hline \multirow{2}{*}{ 4. Education } & Secondary education or below & $12.5 \%$ \\
\hline & Higher education & $87.5 \%$ \\
\hline \multirow{5}{*}{ 5. Marital status } & Not married & $57.8 \%$ \\
\hline & Family/in cohabitation with children & $34.3 \%$ \\
\hline & Family/in cohabitation without children & $4.8 \%$ \\
\hline & Divorced & $1.7 \%$ \\
\hline & Widower/widow & $1.4 \%$ \\
\hline \multirow{5}{*}{$\begin{array}{l}\text { 6. Average monthly income of a } \\
\text { household member (AZN) }\end{array}$} & Up to 300 & $14.1 \%$ \\
\hline & $301-600$ & $28.8 \%$ \\
\hline & $601-1000$ & $26.1 \%$ \\
\hline & 1001 and higher & $15.3 \%$ \\
\hline & Not indicated & $15.6 \%$ \\
\hline
\end{tabular}

Source: World Tourism Organization (UNWTO) World Tourism Barometer. Statistical Annex (2020).

As Figure 4 shows, most of the respondents with a great deal of caution will resume their tourist trips after the end of quarantine measures caused by the COVID-19 pandemic. Respondents are warier of international tourism to the countries most affected by the disease. At the same time, respondents answered that they plan a summer vacation, but its venue changes significantly due to recent events (Fig. 5). Figure 6 focuses on the location and level of service that respondents will use for recreation. The survey results show that $35 \%$ of the respondents plan to rest outside the home in locations with a high level of service. It can be assumed that their choice resulted from the high degree of confidence in the implementation of anti-epidemiological measures and compliance with all recommendations for the health of vacationers. So, first of all, establishments with a high level of service will be able to attract more 
F., Rahmanov, R., Aliyeva, A., Rosokhata, N., Letunovska. Tourism Management in Azerbaijan Under Sustainable Development: Impact of COVID-19

customers at the moment of overcoming the crisis of the tourist industry in Azerbaijan. Another critical factor in the restart of tourism after the abolition of quarantine measures due to the COVID-19 pandemic is the financial capacity of citizens. This indicator is necessary, because, despite the desire and ambition to relax at the highest level of service, the factor that reflects the possibility of such tourism is the financial level. The stability of it has also been significantly shaken in many sectors of the economy. Figure 7 shows respondents' answers to the survey question: «In your opinion, would you have any disposable income to spend after the pandemic / lifting the lockdown measures? ॥
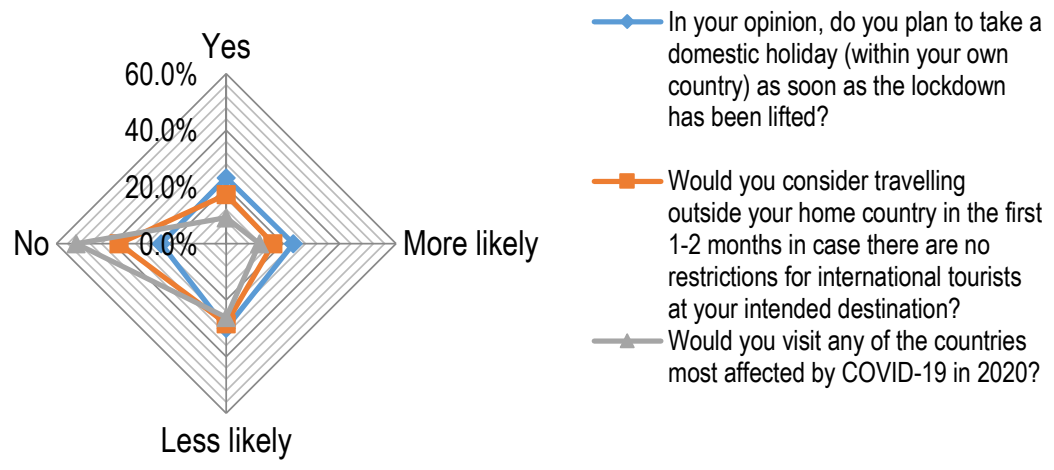

Figure 4. The readiness of Azerbaijani citizens to resume tourist trips after the end of quarantine measures caused by the COVID-19 pandemic

Source: developed by the authors.

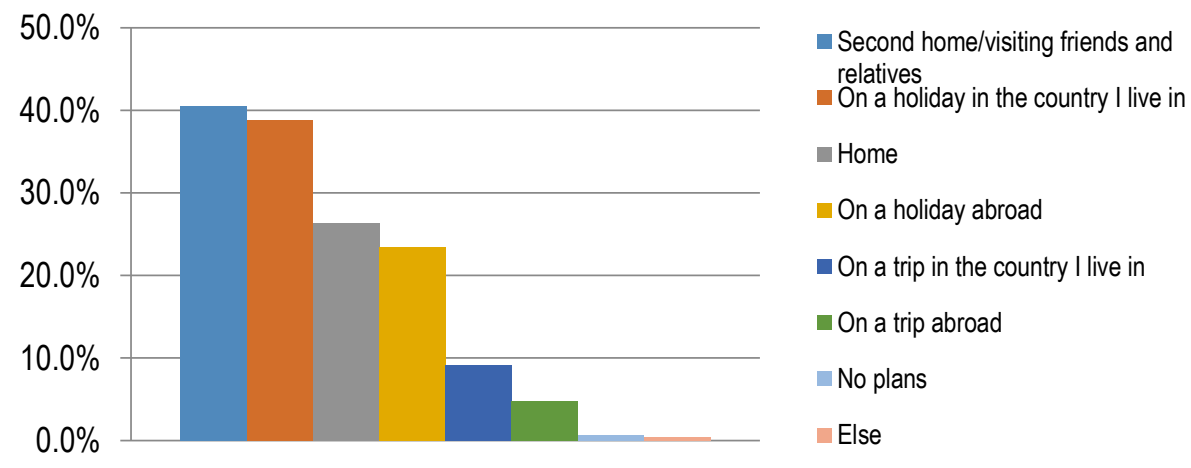

Figure 5. Preferences and intentions of Azerbaijan citizens regarding their future recreation in

Source: developed by the authors. 2020 
F., Rahmanov, R., Aliyeva, A., Rosokhata, N., Letunovska. Tourism Management in Azerbaijan Under Sustainable Development: Impact of COVID-19

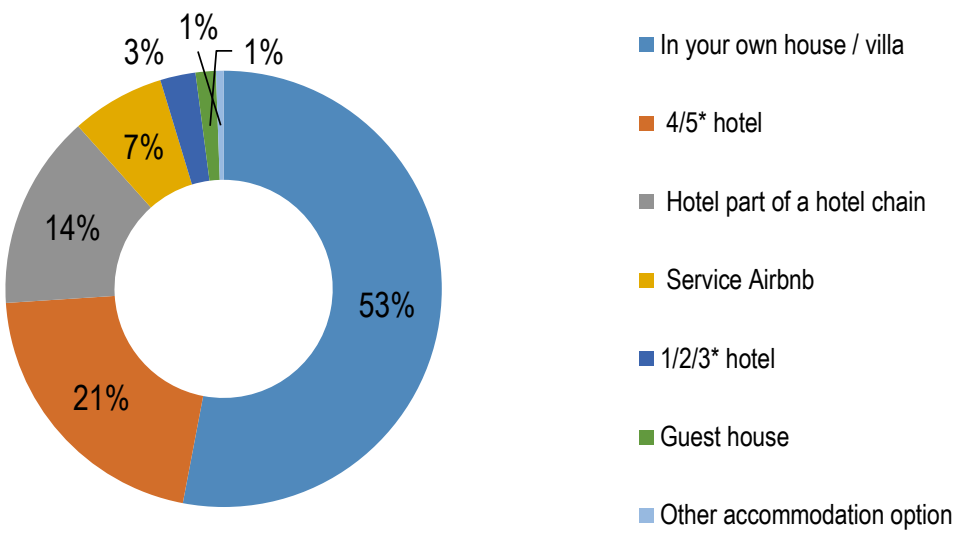

Figure 6. The choice of conditions for recreation after the abolition of quarantine measures due to the COVID-19 pandemic in Azerbaijan

Source: developed by the authors.

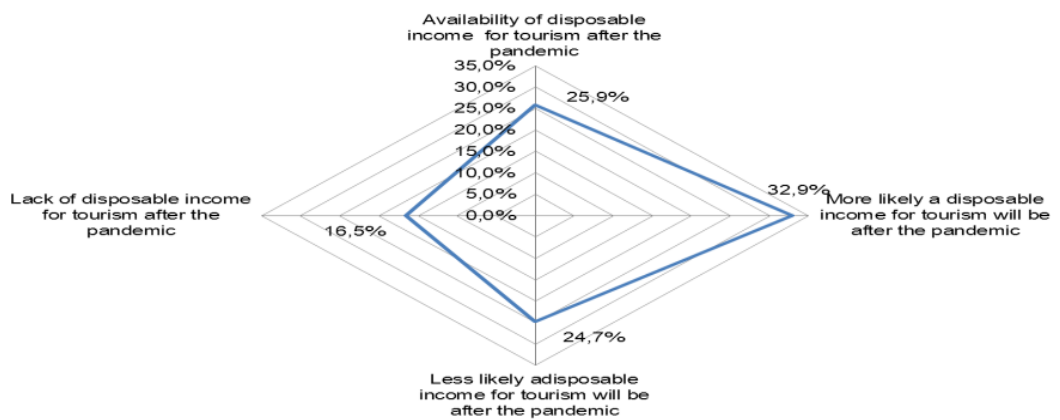

Figure 7. Ability to have resources for tourism after the end of the pandemic

Source: developed by the authors.

As the majority of respondents assess their condition as satisfactory for tourist trips, one can conclude that about positive aspects for the restart of the tourism industry after the end of quarantine measures and gives a chance to develop and implement a new modified tourism business system in Azerbaijan. Nevertheless, to understand what measures need to be implemented and proposed, one should pay attention to the inquiries about how people plan to organize their next tourist vacation (Fig. 8). Thus, the results show that only a quarter of respondents plan to apply to tour operators soon to order travel services, as well as the desire of almost half of respondents to organize a tourist holiday, using their own transport independently, but at the same time, with the opportunity to apply for advice and assistance for booking tickets and hotels. These features and preferences must be taken into account when forming and promoting measures to restart the tourism business in Azerbaijan. An essential aspect of levelling the processes of quarantine measures and declared a state of emergency in many countries is the conscious and systematic support of the state. Of course, those spheres of the country's economy that have experienced significant difficulties deserve special attention. Thus, for resuscitating them as efficiently and quickly as possible, the postulates and principles of systematic revival and recovery must be established. These goals are necessary and relevant in all circumstances, but in the current crisis and pandemic, 
F., Rahmanov, R., Aliyeva, A., Rosokhata, N., Letunovska. Tourism Management in Azerbaijan Under Sustainable Development: Impact of COVID-19

Objective 3 «Ensuring a healthy lifestyle and well-being for people of all ages» certainly deserves the most attention. If we look at tourism not from the standpoint of the economical category, but cultural and health recreation, it is a tool that is useful for achieving this goal, but all measures for the health of citizens must be observed.
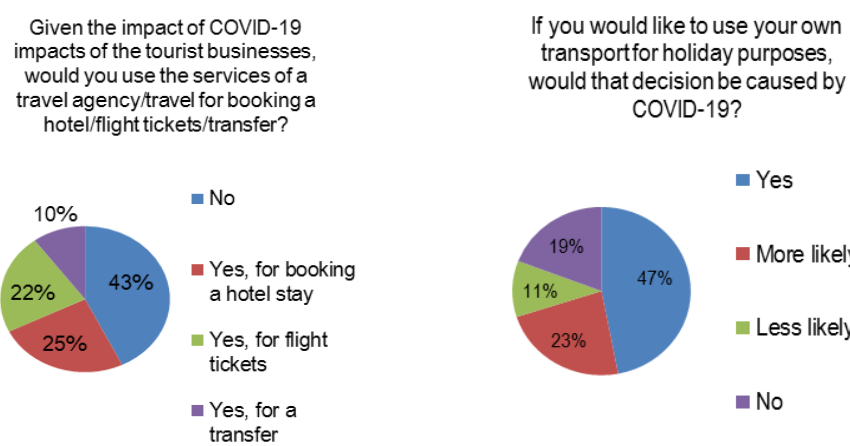
COVID-19?

Figure 8. Answers of the respondents on how they are going to organize tourist trips on occasion after the abolition of quarantine measures from COVID-19

Source: developed by the authors.

Table 3 presents the statistics for the key variables that the authors used in the empirical analysis as part of the research. It shows a range of points of measurement of critical variables of the study. Analyzing the indicators of the critical questions that were offered to the respondents, taking into account the calculated median, one can conclude that the most exciting aspect for people is the opportunity to travel to those countries that have suffered the most from COVID-19 pandemic. The median takes the lowest value for this variable in comparison with all the others. Moreover, an important aspect is the material security for travel and financial ability after the abolition of lockdown measures. At the same time, based on the analysis of statistical averages, the respondents are still convinced that there will be a financial opportunity for travel.

Table 3. Statistics of key variables

\begin{tabular}{|c|c|c|c|c|c|c|}
\hline & $\begin{array}{l}\text { 1. Plans to } \\
\text { take a } \\
\text { domestic } \\
\text { holiday } \\
\text { after } \\
\text { lockdown }\end{array}$ & $\begin{array}{l}\text { 2. Considering } \\
\text { travelling } \\
\text { outside the } \\
\text { home country in } \\
\text { the first } 1-2 \\
\text { months }\end{array}$ & $\begin{array}{l}\text { 3. Intentions to } \\
\text { visit any of the } \\
\text { countries that } \\
\text { have suffered } \\
\text { the most from } \\
\text { COVID-19 }\end{array}$ & $\begin{array}{l}\text { 4. Intentions to } \\
\text { spend } \\
\text { disposable } \\
\text { income after } \\
\text { lifting the } \\
\text { lockdown } \\
\text { measures }\end{array}$ & $\begin{array}{l}\text { 5. Intentions } \\
\text { to use their } \\
\text { own } \\
\text { transport } \\
\text { for holiday } \\
\text { purposes }\end{array}$ & $\begin{array}{l}\text { 6. Plans } \\
\text { to take } \\
\text { an } \\
\text { escorted } \\
\text { tour }\end{array}$ \\
\hline Yes & $23.3 \%$ & $17.3 \%$ & $9.1 \%$ & $25.9 \%$ & $47.0 \%$ & $11.5 \%$ \\
\hline $\begin{array}{l}\text { More } \\
\text { likely }\end{array}$ & $23.7 \%$ & $16.5 \%$ & $11.8 \%$ & $32.9 \%$ & $23.0 \%$ & $18.0 \%$ \\
\hline $\begin{array}{l}\text { Less } \\
\text { likely }\end{array}$ & $30.0 \%$ & $28.3 \%$ & $26.1 \%$ & $24.7 \%$ & $10.8 \%$ & $23.5 \%$ \\
\hline No & $23.0 \%$ & $37.9 \%$ & $53.0 \%$ & $16.5 \%$ & $19.2 \%$ & $47.0 \%$ \\
\hline Median & $23.5 \%$ & $22.78 \%$ & $18.94 \%$ & $25.3 \%$ & $21.10 \%$ & $20.74 \%$ \\
\hline
\end{tabular}

Source: developed by the authors.
Do you have any plans to take an operator in 2020 ?

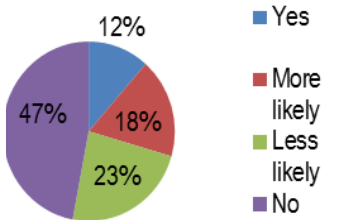

Source: developed by the authors. 
F., Rahmanov, R., Aliyeva, A., Rosokhata, N., Letunovska. Tourism Management in Azerbaijan Under Sustainable Development: Impact of COVID-19

Table 4 displays the correlations between the respondent's answers to the questions. The answer to the question about vacation plans within the home country is practically unrelated to the answers to other questions. The answers to question 2 are practically related to the answers to all questions other than Q1. The analysis showed that when visiting their own country, respondents are more likely to answer about the use of their transport. At the same time, these calculations show how much more significant changes in one or more of these values will be due to changes in others. If the correlation is positive, then with the growth of one variable, the second tends to increase, and if the sign is negative, then decrease. For example, it is evident a significant positive relationship between plans to choose an organized tour and visiting other countries. Whereas when taking a holiday in a domestic country, respondents are not inclined to choose trips organized by tour operators.

Table 4. Correlation of values of key questions

\begin{tabular}{|l|c|c|c|c|c|c|}
\hline & Q1 & Q2 & Q3 & Q4 & Q5 & Q6 \\
\hline Q1 & 1,000 & & & & & \\
\hline Q2 & 0,148 & 1,000 & & & & \\
\hline Q3 & $-0,027$ & 0,980 & 1,000 & & & \\
\hline Q4 & 0,057 & $-0,902$ & $-0,881$ & 1,000 & & \\
\hline Q5 & $-0,612$ & $-0,583$ & $-0,536$ & 0,185 & 1,000 & \\
\hline Q6 & $-0,121$ & 0,940 & 0,988 & $-0,815$ & $-0,541$ & 1,000 \\
\hline
\end{tabular}

Source: developed by the authors.

Analysis of the covariance of respondents' answers to key research questions confirms the conclusions of the correlation analysis. In Table 5, the value of the variables is nonzero, which shows some relationships between the answers to the questions. It confirms the hypothesis put forward by the authors that potential tourists who plan to travel abroad in the future take into account when organizing the holiday virtually all the factors identified by researchers: financial capacity, opportunities for tour operators, risks in other countries.

Table 5. The covariance of values of key questions

\begin{tabular}{|l|c|c|c|c|c|c|}
\hline & Q1 & Q2 & Q3 & Q4 & Q5 & Q6 \\
\hline Q1 & 0,0008 & & & & & \\
\hline Q2 & 0,0004 & 0,0077 & & & & \\
\hline Q3 & $-0,0001$ & 0,0150 & 0,0303 & & & \\
\hline Q4 & 0,0001 & $-0,0046$ & $-0,0089$ & 0,0034 & & \\
\hline Q5 & $-0,0024$ & $-0,0069$ & $-0,0126$ & 0,0014 & 0,0181 & \\
\hline Q6 & $-0,0005$ & 0,0111 & 0,0230 & $-0,0063$ & $-0,0097$ & 0,0179 \\
\hline
\end{tabular}

Source: developed by the authors.

According to the results, the researchers' hypotheses were confirmed in the part of the respondents who plan tourist trips abroad. For other respondents who plan a vacation only within their country, the results of the correlation analysis of the relationship between questions 1 and 5 show that they plan to visit tourist destinations by their transport. At the same time, other factors identified in the study are less significant for them. Respondents who plan foreign tourist trips will take into account all factors without exception. The availability of financial opportunities will be poorly taken into account when travelling within the country, in particular by own transport. Accordingly, this type of travel is more affordable and less expensive.

Conclusions. Recommendations that must be taken into account in the process of restoring the tourism industry after the termination of quarantine measures are: 
F., Rahmanov, R., Aliyeva, A., Rosokhata, N., Letunovska. Tourism Management in Azerbaijan Under Sustainable Development: Impact of COVID-19

- community orientation towards domestic tourism, namely green tourism and ecotourism. The advantages of this type of tourism are that it will provide an opportunity primarily to rehabilitate representatives of medium and small businesses;

- increase in options for tourist trips in small groups accompanied by 1-2 guides;

- adherence to high standards of service quality due to the caution of citizens to comply with all antiepidemiological measures;

- creation of a flexible system of travel within the country by own transport, creation of automobile tourist routes in the middle of the country and organization of the necessary infrastructure for this purpose;

- introducing the reservation system with easy access to the cancellation of reservations and the return of advances in the event of a rapid change in the epidemiological situation;

- providing the opportunity to book not complex tourist tours, but individual services in terms of tourist recreation (booking rooms without meals, booking tickets for transport without additional services, etc.);

- state audit and certification of institutions and organizations that provide tourism services and/or are involved in the tourism industry of the country. A system of precise control will improve the quality of service, as well as increase the level of confidence of tourists in the community.

Author Contributions: conceptualization, F. R., A. R., N. L.; methodology, F. R., R. A.; software, R. A., A. R.; validation, F. R., N. L.; formal analysis, A. R.; investigation, R. A.; resources, F. R.; data curation, F. R, A. R.,N. L.; writing-original draft preparation, A. R., N. L.; writing-review and editing, R. A., N. L.; visualization, A. R.; supervision, F. R., R. A.; project administration, R. A.

\section{References}

Adongo, C. A., Taale, F., \& Adam, I. (2018). Tourists' values and empathic attitude toward sustainable development in tourism. Ecological Economics, 150, 251-263. [Google Scholar] [CrossRef]

Aimagambetov, E., Bugubaeva, R., Bespayeva, R., \& Tashbaev, N. (2017). Model of sustainable development of tourism industry in Kazakhstan (regional perspective). [Google Scholar] [CrossRef]

Alexis-Thomas, C. (2020). An examination of issues related to tourism and health and well-being as a sustainable development goal by tourism providers in Tobago. Worldwide Hospitality and Tourism Themes. [Google Scholar] [CrossRef]

Allahverdiyeva, L.A. (2017). Formation of competitive tourism in Azerbaijan. Institute of Economics of ANAS, Baku, 2017.

Assembly, G. (2015). Resolution adopted by the General Assembly on September 19 2016. A/RES/71/1, October 32016 (The New York Declaration). [Google Scholar]

Baranovskyi O. I., Khutorna M. E. Methodology of forming the system of ensuring financial stability of credit institutions. Financial and credit activities: problems of theory and practice. 2018. Vol. 4. No 27. P. 4-13. [Google Scholar] [CrossRef]

Bilan, Y., Lyeonov, S., Lyulyov, O., \& Pimonenko, T. (2019). Brand management and macroeconomic stability of the country. Polish Journal of Management Studies, 19, 61-74 [CrossRef]

Bilan, Y., Vasilyeva, T., Lyulyov, O., \& Pimonenko, T. (2019). EU vector of Ukraine development: linking between macroeconomic stability and social progress. International Journal of Business \& Society, 20(2), 433-450. [Google Scholar]

Dzwigoł, H., Dzwigoł-Barosz, M. (2018). Scientific Research Methodology in Management Sciences, 2(25), 242-237. [CrossRef

Hatipoglu, B., Ertuna, B., \& Salman, D. (2019). Corporate social responsibility in tourism as a tool for sustainable development. International Journal of Contemporary Hospitality Management. [Google Scholar] [CrossRef]

Ibragimov, Z., Vasylieva, T., \& Lyulyov, O. (2019). The national economy competitiveness: effect of macroeconomic stability, renewable energy on economic growth. Economic and Social Development: Book of Proceedings, 877-886. [Google Scholar]

Kabote, F., Mamimine, P. W., \& Muranda, Z. (2017). Domestic tourism for sustainable development in developing countries. African Journal of Hospitality, Tourism and Leisure, 6(2), 1-12. [Google Scholar]

Kamata, H. (2016). A Segmentation Analysis of Japanese Spa Tourists. Journal of Tourism \& Services, 7(12). [Google Scholar]

Kuzior, A., Kwilinski, A., Tkachenko, V., \& Tkachenko, V. (2019). Sustainable development of organizations based on the combinatorial model of artificial intelligence. Entrepreneurship and Sustainability Issues, 7(2), 1353-1376. [Google Scholar] [CrossRef]

Kuznyetsova A. Ya., Zherebylo I. V. Klipkova O. I. Kozmuk N. I. Creation of the value of national enterprises with the help of the innovation centers in the cluster formations. Financial and credit activities: problems of theory and practice. 2019. Vol. 2. No 29. P. 391-402. [Google Scholar] [CrossRef] 
F., Rahmanov, R., Aliyeva, A., Rosokhata, N., Letunovska. Tourism Management in Azerbaijan Under Sustainable Development: Impact of COVID-19

Kuznyetsova A. Ya., Voznyak H. V., Zherebylo I. V. Social and economic effects of inter-budgetary relations' decentralization in Ukraine: assessment and challenges. Financial and credit activities: problems of theory and practice. 2018. Vol. 4. No 27. P. 446456. [Google Scholar] [CrossRef]

Kwilinski, A., Vyshnevskyi, O., \& Dzwigol, H. (2020). Digitalization of the EU Economies and People at Risk of Poverty or Social Exclusion. Journal of Risk and Financial Management, 13(7), 142. [Google Scholar] [CrossRef]

Lee, T. H., \& Jan, F. H. (2019). Can community-based tourism contribute to sustainable development? Evidence from residents' perceptions of the sustainability. Tourism Management, 70, 368-380. [Google Scholar] [CrossRef]

Lee, T. J., Han, J. S., \& Ko, T. G. (2020). Health-Oriented Tourists and Sustainable Domestic Tourism. Sustainability, 12(12), 4988. [Google Scholar] [CrossRef]

Martín, J. M., Salinas Fernandez, J. A., Rodríguez Martín, J. A., \& Jimenez Aguilera, J. D. D. (2017). Assessment of the tourism's potential as a sustainable development instrument in terms of annual stability: Application to Spanish rural destinations in process of consolidation. Sustainability, 9(10), 1692. [Google Scholar] [CrossRef]

Mazilu, M., Dumitrescu, D., \& Gheorgheci, S. (2017). Romanian tourism industry and sustainable development. Journal of Environmental Protection and Ecology, 18(2), 623-631. [Google Scholar]

Melnyk, L., Sineviciene, L., Lyulyov, O., Pimonenko, T., \& Dehtyarova, I. (2018). Fiscal decentralization and macroeconomic stability: the experience of Ukraine's economy. Problems and Perspectives in Management, 16(1), 105-114. [Google Scholar]

Mura, L., \& Kaizar, P. (2019). Small Businesses in Cultural Tourism in a Central European Country. Journal of Tourism and Services, 10(19), 40-54. [Google Scholar] [CrossRef]

Miskiewicz, R., \& Wolniak, R. (2020). Practical Application of the Industry 4.0 Concept in a Steel Company. Sustainability, 12(14), 5776. [Google Scholar] [CrossRef]

Rosokhata A.,\& Saher L. (2020). Individual issues of economic security: the study of the impact of changes in migration processes on countries economic and innovative development. Visnyk of Sumy State University. Economy, 1, 62-74. Retrieved from https://visnyk.fem.sumdu.edu.ua/issues/1 2020/1 20207 Saher.pdf

Rosokhata, A., Saher, L., Stoyanets, N., \& Butrym, O. (2020). Impact Of Highly Qualified Personnels Migration On Economic And Innovative Development. 35th IBIMA Conference: 1-2 April 2020, Seville, Spain. Retrieved from https://ibima.org/acceptedpaper/impact-of-highly-qualified-personnels-migration-on-economic-and-innovative-development/

Saarinen, J. (2018). Beyond growth thinking: the need to revisit sustainable development in tourism. Tourism Geographies, 20(2), 337-340. [Google Scholar] [CrossRef

Shcherbakova, N. (2018). State and Trends of Sustainable Development of Tourism in Ukraine and the World. Journal of Environmental Management and Tourism (JEMT), $9(08$ (32)), 1712-1724. [Google Scholar] [CrossRef]

Tielietov, O. S., Letunovska, N. Y., \& Melnyk, Y. M. (2019). Four-vector efficiency of infrastructure in the system of providing regional socially significant needs taking into account the concept of marketing of changes. [Google Scholar] [CrossRef]

Van Dyk, A., Tkaczynski, A., \& Slabbert, E. (2019). Repeat tourism, destination image and behavioural intentions: implications for sustainable development in South Africa. Tourism Recreation Research, 44(3), 392-398. [Google Scholar] [CrossRef]

Vucetic, A. S.. (2018). Importance of environmental indicators of sustainable development in the transitional selective tourism destination. International Journal of Tourism Research, 20(3), 317-325. [Google Scholar] [CrossRef]

Wang, J. (2017). Economic and cultural impact of tourism marketing. Marketing and Management of Innovations, 3, 53-59. [CrossRef

World Tourism Organization (UNWTO) (2019). International Tourism Highlights. Retrieved from https://www.unwto.org/publications

World Tourism Organization (UNWTO) (2020). World Tourism Barometer. Retrieved from https://www.unwto.org/publications

World Tourism Organization (UNWTO) (2020). World Tourism Barometer. Statistical Annex. Retrieved from https://www.unwto.org/publications

Yevdokimov, Y., Melnyk, L., Lyulyov, O., Panchenko, O., \& Kubatko, V. (2018). Economic freedom and democracy: Determinan factors in increasing macroeconomic stability. Problems and Perspectives in Management, 16(2), 279-290. [Google Scholar] [CrossRef]

Фархад Рахманов, Dr. Sc., Азербайджанський державний економічний університет, Азербайджанська Республіка

Рамілія Алієва, Ph.D., Академія державного управління при Президентові Азербайджанської Республіки, Азербайджанська Республіка

Анна Росохата, Ph.D., Сумський державний університет, Україна

Наталія Летуновська, Ph.D., Сумський державний університет, Україна

Менеджмент туризму Азербайджану в рамках концепції сталого розвитку: вплив COVID-19

Cтаття присвячена розгляду актуального питання 2020 року щодо впливу пандемії Covid-19 на туристичну галузь світу, загалом, та Азербайджану, зокрема. У роботі визначено шляхи виходу з кризи за умови дотримання иілей сталого розвитку. Основною метою дослідження є формування рекомендацій щодо нівелювання негативних наслідків Covid-19 у туристичній галузі Азербайджану, за умови дотримання цілей сталого розвитку. Систематизація наукових 
F., Rahmanov, R., Aliyeva, A., Rosokhata, N., Letunovska. Tourism Management in Azerbaijan Under Sustainable Development: Impact of COVID-19

напрацювань з означеної проблематики засвідчила, що питання маркетингу туризму в кризових умовах є завжди складним та багатогранним питанням. Автори зазначили, що розвиток туристичної сфери сприяє нівелюванню та вирішенню проблем в інших сфрерах економіки приймаючих країн. У статті представлена динаміка глобального розвитку туристичної галузі та групи країн Middle East, до якої входить Азербайджан. Проведено порівняльний аналіз основних кількісних показників розвитку туризму Азербайджану, сусідніх країн та України. Актуальність даного дослідження полягає в тому, що для ефективного та планомірного рестарту туристичної діяльності після завершення карантинних заходів, необхідною умовою є розуміння вподобань, запитів та побоювань споживачів щодо туристичних послуд. У ході роботи проведено маркетингове соціологічне дослідження громадян Азербайджану з метою визначення потенційного впливу COVID-19 на туристичну галузь. Опитування проведено 13-21 квітня 2020 колективом дослідників з Університету Нортгемптона (Великобританія), Національного інституту геофізики, геодезії та геограсрії Болгарської академії наук, Університету національної та світової економіки (Болгарія). За отриманими результатами визначено основні запити громадян Азербайджану при рестарті туризму в країні. У статті проаналізовано иілі сталого розвитку, анонсовані згідно з Резолюцією, прийнятою Генеральною асамблеєю ООН 25 вересня 2015 року та такі, що стають максимально актуальними у розрізі подій 2020 року та є викликом для сучасного суспільства, загалом, та Азербайджану зокрема. Враховуючи отримані результати, у роботі сформовано рекомендації щодо рестарту туристичної галузі Азербайджану за умови дотримання та реалізації цілей сталого розвитку. Результати даного дослідження можуть бути корисними для управлінських інституцій Азербайджану та країн, туристична галузь яких мала динамічний та стрімкий розвиток впродовж останніх декількох років, а також для представників індустрії туризму Азербайджану, які формують їі інфраструктуру на національному, регіональному та місцевому рівнях.

Ключові слова: туризм Азербайджану, цілі сталого розвитку, вплив COVID-19, соціальні аспекти туризму, вибір туристів, рестарт туризму, здоров'я громадян

Manuscript received: 02.07.2020

(C) The author(s) 2020. This article is published with open access at Sumy State University 